\title{
RABBIT GROWTH, CARCASS CHARACTERISTIC, DIGESTION, CAECAL FERMENTATION, MICROFLORA, AND SOME BLOOD BIOCHEMICAL COMPONENTS AFFECTED BY ORAL ADMINISTRATION OF ANAEROBIC PROBIOTIC $\left(\right.$ ZAD $\left.^{\circledR}\right)$
}

\author{
A. S. Abdel-Azeem ${ }^{1}$, A. A. Hassan ${ }^{2}$, M.M. Basyony ${ }^{2}$ and Salma H. Abu Hafsa ${ }^{3}$ \\ ${ }^{1}$ Poultry Department, Faculty of Agriculture, Fayoum University, Egypt. \\ ${ }^{2}$ Animal Production Research Institute, Agricultural Research Center, Dokki Giza, Egypt. \\ ${ }^{3}$ Livestock Research Department, Arid Lands Cultivation Research Institute, City of Scientific Research \\ and Technological Applications, New Borg El-Arab, P. O. Box: 21934 Alexandria, Egypt.
}

Corresponding author: A. S. Abdel-Azeem asa10@fayoum.edu.eg

(Received 12/9/201, accepted 1/11/2018)

\section{SUMMARY}

$\mathrm{T}$ he current research designed to study the influences of diverse doses of oral administration of anaerobic probiotic $(\mathrm{ZAD} \AA$ ) on growth performance, carcass characteristic, digestibility coefficient, caecal activity, microflora and some blood biochemical components of growing rabbits. At 6 weeks (average body weight $539.87 \pm 13.35 \mathrm{~g}$ ), one hundred and eighty weaned male rabbits from New Zealand White (NZW) were randomly distributed to four groups. The control group received orally $0.0 \mathrm{ZAD}^{\circledR}$; the experimental groups administrated orally with $0.25,0.5$ and $1.0 \mathrm{ml} \mathrm{ZAD}{ }^{\circledR} / \mathrm{rabbit} /$ day, respectively. The experimental period lasted for 8 weeks. Groups $0.25 \mathrm{ZAD}^{\circledR}$ and $0.5 \mathrm{ZAD}^{\circledR}$ had improved feed conversion ratio and body weight gain and the lowest mortality rate. In comparison with the control and $1.0 \mathrm{ZAD}^{\circledR}$ groups, the groups $0.25 \mathrm{ZAD}^{\circledR}$ and $0.5 \mathrm{ZAD}$ caused a significant increase $(\mathrm{P} \leq 0.05)$ in nitrogen utilization, nutritive value and digestibility coefficients. The different doses of $\mathrm{ZAD}^{\circledR}$ had improved dressing percentage and percentage of edible parts, although parts of total non-edible were decreased $(\mathrm{P} \leq 0.001)$ compared to the group of control. As well as, cecum activity (caecum $\mathrm{pH}$, total volatile fatty acids, acetic, propionic and butyric acid) were improved significantly by administrated orally different doses of probiotic $\mathrm{ZAD}^{\circledR} 0.25,0.5$ and $1.0 \mathrm{ml} / \mathrm{rabbit} / \mathrm{day}$ compared with the control group. The opposite trend was observed in ammonia concentration which had been reduced significantly by administrated all doses of $\mathrm{ZAD}^{\circledR}$. In addition, a total number of anaerobic bacteria were less than those of total microbial count and coliform group but, they have the same trend of decreasing the number as the amount of anaerobic probiotic $\mathrm{ZAD}^{\circledR}$ increased. Also, fermentation of lactobacilli take the opposite trend as the amount of probiotic $\mathrm{ZAD}^{\circledR}$ increased the lactobacilli number increased. As streptococci isolated was lower than lactobacilli group. As the concentration of probiotic ZAD ${ }^{\circledR}$ increased isolates numbers decreased, also lactobacilli enumeration increased. The serum total protein, albumin, globulin, and albumin: globulin concentration of rabbits received probiotic $\mathrm{ZAD}^{\circledR}$ groups were significantly augmented compared with the group of control. On the contrary, levels of creatinine and urea in rabbit serum were not significantly affected by probiotic oral administration $\mathrm{ZAD}^{\circledR}$. Alanine aminotransferase and aspartate aminotransferase enzymes of serum were significantly decreased with augmenting levels of ZAD ${ }^{\circledR}$. Serum levels of total cholesterol (TC), lipoproteins of low density (LDL), very low-density lipoproteins, triglycerides, total lipids, and LDL: lipoproteins of high density (HDL) ratio were significantly decreased with augmenting levels of $\mathrm{ZAD}^{\circledR}$. But, the HDL: TC and HDL: LDL ratio augmented significantly with probiotic oral administration $\mathrm{ZAD}^{\circledR}$ levels.

Keywords: ZAD ${ }^{\circledR}$, growth performance, digestible coefficient, caecum activity, nitrogen balance, rabbit.

\section{INTRODUCTION}

Because of the pollution of feed with pathogenic bacteria and their associated impacts on the animal, such as increased mortality or reduce weight gains, both the food production and the feed industry sectors 
are still suffering enormous losses. Pathogenic bacteria are constantly existing in the alimentary canal, but it is determined by the balance between pathogenic and beneficial bacteria that a disease will occur or not. Preserving a healthy equilibrium within the intestine between all microflora is known as symbiosis (Jensen, 1980) and may be affected by microflora endemic bacteria. Bacteria considered useful to the intestine, comprising bacteria creating lactic acid like Lactobacillus spp., avoid the propagation of pathogens such Salmonella spp. by competitively excluded of receptor and nutrient sites on the intestinal wall (Thomke and Elwinger, 1998). It has been observed in recent decades that the development of rabbit production is the result of the contributions in genetics, management, nutrition, health, environment and other fields of certain technologies and innovations. Other alternative feed additives are currently being adopted to fill the antibiotic gap. Due to the common problem of reducing consumer agreement of antibacterial growth promoters and increasing bacterial resistance, various substances called natural growth promoters (NGPs) have been recognized as active and benign alternatives to antibacterial growth promoters.

A large number of NGPs, including immune-boosters, probiotics, and prebiotics are currently available on the market. Under this point of view, the anaerobic probiotic technology (ZAD) ${ }^{\circledR}$ may be a substitute for antibiotic growth promoters in the feeding idea (Gado et al., 2017). The ZAD® is a patented product manufactured by the Academy of Scientific Research and Technology, Egypt and an enzyme biotechnology product from natural sources to raise the anaerobic bacteria cellulase enzymes levels that can transform polysaccharide by the enzyme catalytic process to monosaccharide. The product is designed in form liquid to provide tools to improve the nutritional value of fibrous materials and to improve the overall digestion of animals. It includes the subsequent activity of enzymes such as $6.2 \mathrm{U} / \mathrm{g}$ hemicellulase and $8.2 \mathrm{U} / \mathrm{g}$ cellulose, as well as $12.3 \mathrm{U} / \mathrm{g}$ protease and $64.4 \mathrm{U} / \mathrm{mg}$ amylase (Gado et al., 2011, Gado and Salem, 2013 and Gado et al., 2017), besides the anaerobic bacteria that create these enzymes (Abdel-Aziz et al., 2014, 2015), additionally, the patent number is 22155 (Gado, 1997).

Anaerobic probiotic $(\mathrm{ZAD} \AA)$ is a dietary 1.5 liter for rabbits that helps the animals to overcome the stress of heat. It augmented production of milk for rabbits, raised the daily average gain, enhanced throughout the physiological aspects and lowered the rabbit mortality rate.

It is relatively new to know the effects of synergistically acting anaerobic probiotic blends to the rabbit with mixture enzymes. The main aims of this report are hence to study the effect of anaerobic probiotic ZAD oral intake on growth performance, mortality, digestible nutrient coefficient, carcass characteristics, caecum activity and some blood biochemical components of New Zealand White (NZW) growing rabbits.

\section{MATERIALS AND METHODS}

\section{Experimental design:}

This study took place at Al - Noubaria Research Station, Research Institute for Animal Production, Research Center for Agriculture, Egypt, to investigating the effect of oral administration anaerobic probiotic $\left(\mathrm{ZAD}^{\circledR}\right)$ on growth performance, nutrient digestibility coefficient, nitrogen balance, caecum activity, caecum microflora, and some blood biochemical components of NZW rabbits for 56 days. In a simple randomized design experiment, one hundred and eighty weaned male rabbits at 6 weeks old (average body weight $539.87 \pm 13.35 \mathrm{~g}$ ) from NZW were distributed randomly to four dietary groups (45 in each group; three replicates 15 for each replicate). The control group was administered $1.0 \mathrm{ml}$ distilled water $\left(0.0 \mathrm{ZAD}^{\circledR}\right)$ orally once daily, the trial groups were administered anaerobic probiotic $\left(\mathrm{ZAD}^{\circledR}\right)$ at levels $0.25,0.5$ and 1.0 $\mathrm{ml} /$ rabbit/ day (groups $0.25,0.5$, and $1.0 \mathrm{ZAD}^{\circledR}$, respectively) were oral gavage administration/each rabbit. Doses were given once daily via gavage for 56 consecutive days. This method could be improved eliminates risks of variability in intake between individual animals which may arise when substances are administered through delivery in water.

\section{Diets and housing of the experiment:}

The rabbits were kept in cages from galvanized wire individually $(50 \times 40 \times 35 \mathrm{~cm})$ under a 16:8 h lightdark cycle until marketing at 14 weeks of age. Pelleted feed ad libitum was fed to all rabbits. According to Lebas (2004), the experimental diets were prepared to fulfill the nutrient needs of growing rabbits. All rabbits were reared under the same conditions of hygiene, management, and the environment. Rabbits were kept in a building was well-ventilated; through nipples from stainless-steel fastened in every cage, fresh 
water was automatically obtainable the whole time. Body weight was determined every week throughout the experimental period and an average gain of body weight was computed. Feed intake (FI) was accurately measured by grams throughout the experimental period for each rabbit per week. During the computation of FI and feed conversion ratio (FCR), feed residuals collected daily from each cage, weighed and taken into account. The composition and calculated analyses of the experimental diets and feed ingredients are presented in Table (1). According to AOAC (2000), chemical analyses of rations in the experiment were performed.

Table (1). Composition and calculated analyses (\%) of the experimental diets on dry matter basis.

\begin{tabular}{lclc}
\hline \multirow{2}{*}{ Feed ingredients \% } & Control diet & \multicolumn{2}{c}{$\begin{array}{c}\text { Calculated analyses } \\
\text { (according to NRC, 1977) }\end{array}$} \\
\cline { 3 - 4 } & & Item & $\%$ \\
\hline Dried Egyptian clover & 35.00 & dry matter & 89.67 \\
Yellow corn & 10.0 & Crude protein & 17.18 \\
Soybean meal & 17.5 & Crude fiber & 13.05 \\
Barley & 18.0 & Neutral detergent fiber & 37.49 \\
Wheat bran & 15.00 & Ether extract & 3.41 \\
Molasses & 3.00 & Nitrogen-free extract & 56.03 \\
Di- Ca- phosphate & 0.8 & Ash & 10.33 \\
DL-Methionine & 0.10 & Calcium & 0.83 \\
NaCl & 0.30 & Phosphors & 0.31 \\
Vit.-Min. premix ${ }^{1}$ & 0.30 & Methionine & 0.36 \\
Total & 100 & Total sulphur amino acid $(\%)$ & 0.68 \\
& & Digestible energy (Kcal/Kg) & 2519.87 \\
\hline
\end{tabular}

${ }^{I}$ Provided per kilogram diet: vitamin $D_{3}, 450 \mathrm{IU}$; vitamin $A, 6000 \mathrm{IU}$; vitamin $\mathrm{K} 3,1 \mathrm{mg}$; vitamin $\mathrm{E}$, $40 \mathrm{mg}$; vitamin $B_{1}$, $1 \mathrm{mg}$; niacin, $180 \mathrm{mg}$; vitamin $B_{2}, 3 \mathrm{mg}$; vitamin $B_{6}, 39 \mathrm{mg}$; pantothenic acid, $10 \mathrm{mg}$; folic acid, $2.5 \mathrm{mg}$; vitamin $B_{12}, 2.5$ mg; biotin, $10 \mathrm{mg}$; manganese, $15 \mathrm{mg} ; 1200 \mathrm{mg}$; zinc, $35 \mathrm{mg}$; iron, $38 \mathrm{mg}$; choline chloride, copper, $5 \mathrm{mg}$; selenium, $0.05 \mathrm{mg}$; iodine, $0.2 \mathrm{mg}$.

\section{Digestibility trials:}

At the end of the growth experiment (14 weeks of age) digestibility studies were conducted to define the digestibility of nutrients, values of feeding, and experimental diet nitrogen balance. A total number of 20 male rabbits were taken randomly (5 within each treatment) and allotted in different treatment. Animals were stayed in cages separating feces and urine individually. Twice daily at 9 AM and 15 PM experimental diets were obtainable, and additional water was ad libitum supplied. Daily feed consumption survey has been documented. All probable contamination of feed has been eliminated from the feces. Samples of every rabbit's daily feces were taken and oven dried for $48 \mathrm{~h}$ at $60^{\circ} \mathrm{C}$, then grounded and stocked for proximate chemical analysis. By the AOAC (2000) methods samples of feces were evaluated for dry matter (DM), ash, ether extract (EE), crude protein (CP), and crude fiber (CF). According to Cheeke (1987), the nutritive values of the experimental diets were computed as total digestible nutrients (TDN). Digestible energy (DE) was calculated according to Schneider and Flatt (1975) using the following equation: Digestible energy (DE, Kcal/Kg diet)) was calculated as follow: TDN $\times 44.3$. Each animal's urine was collected in a glass container, comprising $10 \mathrm{ml}$ of a 1:1 $\mathrm{H}_{2} \mathrm{O}: \mathrm{HCl}$ sol, to avert potential losses through volatilization and bacterial production. The nitrogen intake (NI) values, excreted feces nitrogen (FN) and urine nitrogen (UN) were acquired by the quantities of feed consumed and excreted nitrogen in feces and urine respectively retained nitrogen was computed as NR $=\mathrm{NI}$ $-(\mathrm{FN}+\mathrm{UN})$. 


\section{Abbdel-Azeem et al.}

\section{Slaughtering and carcass traits:}

At the end of period of growth experiment, ten rabbits male (aged 14 weeks) were selected randomly from each group, fasted for twelve hours, weighed individually and slaughtered immediately. Elimination of tail, pelt, and viscera after complete bleeding and then weighed the carcass and its constituents as edible parts. Additionally weighed as a percentage of pre-slaughter weight performed the non-edible parts comprise large intestine, lung, stomach, spleen, and small intestine. By dividing the hot dressed carcass weight by pre-slaughter weight, the dressing percentage was computed and stated as a percentage.

Gastrointestinal tracts were individually removed from three slaughtered rabbits from each group, weighted cecum and measured the $\mathrm{pH}$ of the caecal content by a digital $\mathrm{pH}$ meter (Model 20, Digital $\mathrm{pH}$ meter for Orion Research). Then, to determine total volatile fatty acids (VFA) and ammonia nitrogen by steam distillation (UDK 139- Semi - Automatic Distillation Unit) according to Warner (1964), the caecal content was collected and filtrated throughout 4 gauze pleats. The Gastrointestinal tracts of slaughter rabbit were washed with $70 \%$ ethanol in order to reduce the number of incidental organisms. After that, the large intestinal tract aseptically cut and separate proximal from the distal part. Then, aseptically opened both parts and the caecum content removed so can retrieve a smear from caecum wall using a bacteriological loop. Then, the loop implanted inside previously made broths (tryptic soy broth, De Man, Rogosa and Sharpe (MRS) broth (CM0359, oxide)) and anaerobically incubated at $37^{\circ} \mathrm{C}$ for 24-48 $\mathrm{h}$. Then each broth from each experimental unit plated on previously made MRS agar and tryptic soy agar plates and anaerobically incubated for $24-48$ hours at $37^{\circ} \mathrm{C}$. Then, choose milky white, circular, convex, elevated and non-pigmented colonies on MRS agar for additional sub-cultured. On MRS agar, the colonies were stained to ensure for a pure culture that was covered with glycerol and kept for more study (Pal et al., 2005).

\section{Total bacterial count using spectrophotometer:}

The caecum aseptically cut, ground using sterile mortars and pestles into a fine paste. Then put that paste in a tube represent each treatment for centrifugation, and then take supernatant to make 10 fold serial dilutions inside 10 tubes previously prepared from tryptic soy broth and MRS broth with one extra tube as a blank where take a known $1 \mathrm{ml}$ volume of supernatant and place it into $9 \mathrm{ml}$ volume of broth in order to produce $10 \mathrm{ml}$ of the dilute solution. So the diluted solution has $1 \mathrm{ml}$ of extract $/ 10 \mathrm{ml}$, producing a 10 -fold dilution. This process can be repeated to make successive dilutions. Then all diluted tubes incubated at $37^{\circ} \mathrm{C}$ for 24-48 h.

The spectrophotometer needs to be adjusted to $100 \%$ transmittance ( $0 \%$ absorbance) for turbidimetric measurements. This is prepared using a sample of the blank tube (without inoculation). Then measure percent transmittance of various dilutions of the bacterial culture and the values converted to an optical density (O.D.) using the slandered formula: Absorbance (O.D.) $=2-\log \%$ Transmittance. Using a wavelength of $570 \mathrm{~nm}$ when the solution is light yellow (tryptic soy broth), and $700 \mathrm{~nm}$ is used for yellow to brown solutions (MRS broth), Record results. Then make a scatter graph, then record CFU's/mL of a new culture.

\section{Blood samples:}

Blood samples collected from slaughtered rabbits and put in centrifuge tubes, left to clot and centrifuged for separation from the serum, up to the biochemical parameters, serum samples were kept at $-20^{\circ} \mathrm{C}$.

\section{Serum parameters of blood biochemical:}

According to Johnson et al. (1999), albumin (A) and total protein were measured; subtracting albumin values from the corresponding total protein values also obtained globulin $(\mathrm{G})$ values, also ratio of albumin to globulin (A/G) was computed. According to Fringes et al. (1972), Richmond (1973), Fawcett and Scott (1960), Fabiny and Ertingshausen (1971), respectively, the blood serum total lipids, and triglycerides, urea, creatinine were gauged using commercial test kits and the spectrophotometer. Total cholesterol (TC), lipoproteins of low density (LDL) and lipoproteins of high density (HDL) have been identified according to Burstein et al. (1970), Wieland and Seidel (1983) and Bogin and Keller (1987), additionally very lowdensity lipoproteins (vLDL) was calculated as one-fifth of triglycerides. Alanine aminotransferase (ALT) and aspartate aminotransferase (AST) and were assayed according to Reitman and Frankel (1957), respectively. 


\section{Statistical analysis}

The experiment data were analyzed using one-way ANOVA from the SAS ® GLM procedure (SAS Institute, 2000), using the following model: $y_{i j}=\mu+T_{i}+e_{i j}$, Where: $\mu=$ Overall mean $y_{i j}$, $T=$ treatment effect and $\mathrm{e}_{\mathrm{ij}}=$ experimental error. Using Duncan multi-range test (Duncan, 1955), the significant differences between means were detected.

\section{RESULTS AND DISCUSSION}

\section{Growth performance:}

Oral administration of anaerobic probiotic $\left(\mathrm{ZAD}^{\circledR}\right)$ of growing NZW rabbits on body weight, FI, FCR and mortality $\%$ are summarized in Table (2). Results presented that the initial live body weight was not significantly different $(\mathrm{P}>0.05)$ between groups. However, average daily gain (ADG) of rabbits by oral administration 0.25 and $0.5 \mathrm{ml} \mathrm{ZAD}{ }^{\circledR} / \mathrm{rabbit} /$ day were significantly $(\mathrm{P} \leq 0.01)$ higher than other groups. Voluntary FI was significantly influenced by oral administration of ZAD ${ }^{\circledR}$. Total FI of rabbits by oral administration of $\mathrm{ZAD}^{\circledR}$ were significantly $(\mathrm{P} \leq 0.01)$ depress than the control group. The results of FI and weight gain were currently reflected on values of the FCR (g feed/g gain), where it was better for rabbits oral administration 0.25 and $\mathrm{ml} \mathrm{ZAD}{ }^{\circledR} / \mathrm{rabbit} /$ day being 2.31 and 2.24 respectively, than 2.46 for $1.0 \mathrm{ZAD}^{\circledR}$ and 2.67 for control group. Mortality\% of rabbit's oral administration 0.25 and $0.5 \mathrm{ml}$ of ZAD were significantly $(\mathrm{P} \leq 0.01)$ lower than those fed other groups. On the other hand, mortality of oral administration of 0.25 and $0.5 \mathrm{ml} \mathrm{ZAD}{ }^{\circledR} / \mathrm{rabbit} /$ day was significantly $(\mathrm{P} \leq 0.01)$ improved than other groups.

A gradual rise in weight of body with doses of probiotic ZAD was noted in this study. The enhancements in weight of body were 10.4, 13.4 and $1.8 \%$ for groups T2, T3, and T4 at 56 days of age respectively.

In this connect, EL-Sagheer and Hassanein (2014) indicated that the use of 1 or $2 \mathrm{~g}$ of Vetazyme/kg diet (probiotic + enzymes) significantly enhanced rabbit body weight compared to those fed the basal diet during the experimental period.

The present results agree with experiments in pre-mature Hy-Plus rabbit reported by Gado and Salem (2014), where $\mathrm{ZADO}^{\circledR}$ up to $5 \mathrm{~g} / \mathrm{kg}$ diet has been inserted without weakening performance. Additionally, Gado et al. (2017) confirmed that a mixture of enzymes obtained from anaerobic bacteria present in ZAD ${ }^{\circledR}$ had a beneficial effect to converts the polysaccharide into monomers by the enzyme catalytic process in growing rabbits.

Table (2): Growth performance and mortality of New Zealand White rabbits (NZW) supplemented different levels of anaerobic probiotics $\left(\mathrm{ZAD}^{\circledR}\right)$.

\begin{tabular}{lcccccc}
\hline & \multicolumn{5}{c}{ Treatment } \\
\cline { 2 - 5 } Item & Control & $\begin{array}{c}0.25 \mathrm{ml} \mathrm{ZAD}^{\circledR} \\
\text { /rabbit/day }\end{array}$ & $\begin{array}{c}0.5 \mathrm{ml} \\
\text { ZAD }^{\circledR} \\
\text { /rabbit/day }\end{array}$ & $\begin{array}{c}1.0 \mathrm{ml} \\
\text { ZAD }^{\circledR}\end{array}$ & SEM $^{\#}$ & P-value $^{2}$ \\
\hline Initial body weight, g & 542.4 & 542.8 & 537.3 & 536.9 & 13.35 & 0.9827 \\
Final body weight, g & $1850.3^{\mathrm{b}}$ & $2043.3^{\mathrm{a}}$ & $2098.9^{\mathrm{a}}$ & $1883.3^{\mathrm{b}}$ & 32.10 & 0.0001 \\
Body weight gain, g & $1307.8^{\mathrm{b}}$ & $1500.6^{\mathrm{a}}$ & $1561.6^{\mathrm{a}}$ & $1346.4^{\mathrm{b}}$ & 32.33 & 0.0001 \\
Feed intake g & $4926.7^{\mathrm{a}}$ & $4696.1^{\mathrm{b}}$ & $4673.3^{\mathrm{b}}$ & $4616.1^{\mathrm{b}}$ & 64.18 & 0.0064 \\
Feed conversion ratio & $2.67^{\mathrm{a}}$ & $2.31^{\mathrm{c}}$ & $2.24^{\mathrm{c}}$ & $2.46^{\mathrm{b}}$ & 0.05 & 0.0001 \\
Mortality \% & $13.00^{\mathrm{a}}$ & $5.00^{\mathrm{c}}$ & $7.00^{\mathrm{c}}$ & $10.00^{\mathrm{b}}$ & 0.072 & 0.0001
\end{tabular}

\#SEM= standard error of the mean; ${ }^{2 ; a, b, c}$ Means within a row having different superscripts are significantly different $(P \leq 0.05)$. 
Besides, Bhatt et al. (2017) showed that supplementation in rabbit diets of probiotics (107 CFU/g concentrate) Lactococcus lactis and Lactobacillus acidophilus increased $(\mathrm{P} \leq 0.05)$ the gain of weight $(24.5$ vs. $22.5 \mathrm{~g} / \mathrm{d}$ ) as compared with the control group. On the contrary, Matusevicius et al. (2006) compared with control group of rabbits, the weight gain of NZW rabbits fed $400 \mathrm{mg} / \mathrm{kg}$ of probiotic Bio Plus $2 \mathrm{~B}^{\circledR}$ was not significantly different. Recently, Sherif (2018) found that rabbits reared under stress summer conditions receiving enzymes at $0.5 \mathrm{~g} / \mathrm{kg}, \beta$-pro ${ }^{\circledR}$ at $0.2 \mathrm{~g} / \mathrm{kg}$, organic acids at $1.0 \mathrm{~g} / \mathrm{kg}$ or their mixture of enzymes, $\beta$ pro $^{\circledR}$ and organic acids in the diet had the positive effects on daily weight gain compared with control group.

In the present study, during the experimental periods, the control group noted the highest FI significant differences between 1.0, 0.25, or $0.5 \mathrm{ZAD}^{\circledR}$. On conflict to our results, Eiben et al. (2004) utilized the supplementation of cellulose in rabbit growing diets between the ages of 23 and 77 days and Oso et al. (2013) and Bhatt et al. (2017) utilized probiotic-supplemented diets had a significantly upper FI compared to the control group.

In the present experiment, the lowest doses of $\mathrm{ZAD}^{\circledR}(0.25$ and $0.5 \mathrm{ml} /$ rabbit $)$ resulted in the best FCR and minimal mortality $(\mathrm{P}=0.0001)$. The better rate of growth, FCR and rate of mortality with oral administration of $\mathrm{ZAD}^{\circledR}$ may be because of including probiotics that can improve the intestinal balance of the host animal, impact of caecal fermentation and the bowel weight in rabbits (Kermauner and Struklec, 1999); improved the status of health and intestinal function of growing rabbits (Trocino et al., 2005 and Kritas et al., 2008). In the other wise, dietary $\beta$-pro ${ }^{\circledR}$ (probiotics + enzymes) or a mixture of organic acids, $\beta$ pro and enzymes can be improving the rabbit performance (Sherif, 2018).

\section{Digestibility and nitrogen balance trials:}

The effect of oral intake of anaerobic probiotic $\left(\mathrm{ZAD}^{\circledR}\right)$ on nutrients digestibility (OM, CP, EE, CF and NFE), nutritive value (DCP, TDN and DE) and nitrogen balance of NZW rabbits is summarized in Table (3). The oral administration of 0.25 and $0.5 \mathrm{ml} \mathrm{ZAD}{ }^{\circledR} / \mathrm{rabbit} /$ day of rabbits were higher $(\mathrm{P} \leq 0.01)$ nutrients digestibility (CP, CF and EE), nutritive values (DCP and TDN), digestible nitrogen and retained nitrogen compared to other groups. Crude protein, $\mathrm{CF}$ and EE digestibility ranged between 72.94-76.69, 49.53-51.73 and 65.53-69.75, respectively. The highest significant of $\mathrm{CP}$ and $\mathrm{CF}$ were recorded for rabbits treated in 0.5 ZAD followed in descending order by rabbits groups treated by 0.25 and $1.0 \mathrm{ml} \mathrm{ZAD}{ }^{\circledR} / \mathrm{rabbit} /$ day. However, EE digestibility was significantly decreased $(\mathrm{P}=0.013)$ with increasing doses of $Z A D^{\circledR}$. Rabbit treated by 0.0 ZAD showed the lowest $\mathrm{CP}$ and $\mathrm{CF}$ digestibility in comparison to the different anaerobic probiotic $\mathrm{ZAD}^{\circledR}$ doses. Organic matter and NFE digestibility between rabbit groups were not significant affected by administration orally with different doses of anaerobic probiotic ZAD ${ }^{\circledR}$.

The nutritive values as DCP, TDN and DE ranged between 12.53-13.18, 55.85-57.54 and 2473.942548.69, respectively. Compared with the control group, the highest significant of DCP was recorded for rabbit treated in $0.5 \mathrm{ZAD}^{\circledR}$ followed in descending order by rabbit groups oral intake 0.25 and $1.0 \mathrm{ml}$ $\mathrm{ZAD}^{\circledR} /$ rabbit/day. However, oral administration of anaerobic probiotic ZAD ${ }^{\circledR}$ did not influenced on the TDN and DE nutritive value.

Effect of oral intake of anaerobic probiotic $\mathrm{ZAD}^{\circledR}$ at different doses on nitrogen metabolism is shown in Table (3). The NI, FN, UN and NR, g/d had significant $(\mathrm{P} \leq 0.01)$ affected. In comparison with the control treatment, the high significant $(\mathrm{P} \leq 0.01)$ of $\mathrm{DN}, \mathrm{g} / \mathrm{d}$ was recorded for rabbits received different doses of anaerobic probiotic $Z_{A D}{ }^{\circledR}$. However, the intake efficiency $\mathrm{N}$ converted to digestible $\mathrm{N}$ (DN/NI, \%) recorded higher significant for rabbits treated in 0.5 and $1.0 \mathrm{ml} \mathrm{ZAD}{ }^{\circledR} / \mathrm{rabbit} /$ day followed in descending order by rabbit groups in $0.25 \mathrm{ml} \mathrm{ZAD}{ }^{\circledR} / \mathrm{rabbit} /$ day as compared with the control treatment. While, higher significant of NR/NI\% and NR/DN\% were recorded for those rabbit administrated orally with 0.25 and $1.0 \mathrm{ml}$ $\mathrm{ZAD}^{\circledR} /$ rabbit/day followed in descending order by rabbit groups intake 0.0 and $0.5 \mathrm{ZAD}^{\circledR} \mathrm{ml}$ $\mathrm{ZAD}^{\circledR} / \mathrm{rabbit} /$ day, respectively.

In this study, nutrient digestibility and nutritive values of $\mathrm{CP}, \mathrm{EE}$ and DCP were higher in the rabbits received oral administration compared to rabbits in the control group. The lowest digestibility of CF were in the rabbits not given probiotic ZAD ${ }^{\circledR}$ as compared with rabbits supplemented with high doses of ZAD ${ }^{\circledR}$. However, ZAD ${ }^{\circledR}$ is a mixture of enzymes obtained from anaerobic bacteria that had a beneficial impact on the digestibility of low quality roughages (Gado et al., 2017). Also, El-Hindawy et al. (1993) found that addition probiotic Lacto-Sacc caused improvement in the digestibility of all the nutrients. Similar improvement was found by Kamra et al. (1996) in CP digestibility and Yamani et al. (1992) in CF digestibility of rabbits. Also, Amber et al. (2004) proved that Lactobacillus acidophilus supplementation caused improving energy and most analytical fractions (CP, EE, and DM) digestibility, comprising CF. This 
improvement tend to that the probiotics stimulate the enzyme production by the host (Mateos et al., 2010), perhaps nutrient digestibility may be improved in probiotic-supplemented groups. The present study showed a similar trend followed by nitrogen utilization as a percentage of intake and absorption. The data of $\mathrm{N}$ balance were well correlated with the growth performance in different groups. This improvement is due to the probiotics $\mathrm{ZAD}^{\circledR}$ oral administration colonizing the intestine, which contributes to maintaining the flora balance, which in the end supplies an intestinal fence versus pathogens (Bhatt et al., 2017). A higher digestibility of $\mathrm{CP}$ and $\mathrm{EE}$ in $\mathrm{ZAD}^{\circledR}$ treated groups could result from maintaining a relatively better gastrointestinal health and environment of bowel that reinforced improvement in $\mathrm{N}$ use and efficient FCR beside growth.

Table (3): Effects of $\mathrm{ZAD}^{\circledR}$ supplement on apparent digestibility and nitrogen retention of growing rabbits.

\begin{tabular}{|c|c|c|c|c|c|c|}
\hline \multirow[t]{2}{*}{ Item } & \multicolumn{4}{|c|}{ Treatments } & \multirow[b]{2}{*}{$\mathrm{SEM}^{\#}$} & \multirow[b]{2}{*}{ P-value ${ }^{2}$} \\
\hline & Control & $\begin{array}{l}0.25 \quad \mathrm{ml} \\
\mathrm{ZAD}^{\circledR} \\
/ \text { rabbit/day }\end{array}$ & $\begin{array}{l}0.5 \quad \mathrm{ml} \\
\mathrm{ZAD}^{\circledR} \\
\text { /rabbit/day }\end{array}$ & $\begin{array}{l}1.0 \mathrm{ml} \\
\mathrm{ZAD}^{\circledR} \\
/ \text { rabbit/day }\end{array}$ & & \\
\hline \multicolumn{7}{|l|}{ Nutrients digestibility (\%) } \\
\hline Organic matter & 59.52 & 61.04 & 61.46 & 60.30 & 1.32 & 0.7981 \\
\hline Crude protein & $72.94^{\mathrm{b}}$ & $75.48^{\mathrm{a}}$ & $76.69^{\mathrm{a}}$ & $74.70^{\mathrm{ab}}$ & 0.84 & 0.0108 \\
\hline Crude fiber & $49.53^{b}$ & $51.19^{\mathrm{a}}$ & $51.73^{\mathrm{a}}$ & $49.77^{\mathrm{b}}$ & 0.50 & 0.0130 \\
\hline Ether extract & $65.53^{\mathrm{b}}$ & $68.47^{\mathrm{a}}$ & $69.75^{\mathrm{a}}$ & $68.27^{\mathrm{a}}$ & 1.16 & 0.0082 \\
\hline $\begin{array}{l}\text { Nitrogen-free extract } \\
\text { Nutritive value }(\%)\end{array}$ & 64.46 & 64.45 & 64.53 & 66.42 & 1.11 & 0.6010 \\
\hline Digestible crude protein & $12.53^{\mathrm{b}}$ & $12.97^{\mathrm{ab}}$ & $13.18^{\mathrm{a}}$ & $13.01^{\mathrm{ab}}$ & 0.14 & 0.0109 \\
\hline Total digestible nutrient & $55.15^{\mathrm{b}}$ & $57.25^{\mathrm{a}}$ & $57.54^{\mathrm{a}}$ & $56.76^{\mathrm{a}}$ & 0.73 & 0.0074 \\
\hline $\begin{array}{ll}\text { Digestible } & \text { energy } \\
\text { (Kcal/Kg) } & \\
\text { Nitrogen balance } & \end{array}$ & 2473.9 & 2536.1 & 2549.0 & 2514.6 & 45.5 & 0.7467 \\
\hline$\overline{\text { Nitrogen intake }}(\mathrm{NI}, \mathrm{g} / \mathrm{d})$ & $2.61^{\mathrm{c}}$ & $2.96^{\mathrm{a}}$ & $2.78^{\mathrm{b}}$ & $2.85^{\mathrm{ab}}$ & 0.04 & 0.0029 \\
\hline Fecal nitrogen (FN, g/d) & $0.70^{\mathrm{ab}}$ & $0.72^{\mathrm{a}}$ & $0.67^{\mathrm{b}}$ & $0.69^{\mathrm{ab}}$ & 0.01 & 0.0520 \\
\hline $\begin{array}{l}\text { Urinary nitrogen (UN, } \\
\mathrm{g} / \mathrm{d} \text { ) }\end{array}$ & $0.62^{\mathrm{b}}$ & $0.68^{\mathrm{ab}}$ & $0.70^{\mathrm{a}}$ & $0.64^{\mathrm{ab}}$ & 0.02 & 0.0104 \\
\hline $\begin{array}{l}\text { Digestible nitrogen (DN, } \\
\mathrm{g} / \mathrm{d})^{1}\end{array}$ & $1.91^{\mathrm{b}}$ & $2.23^{\mathrm{a}}$ & $2.11^{\mathrm{a}}$ & $2.17^{\mathrm{a}}$ & 0.05 & 0.0109 \\
\hline $\begin{array}{l}\text { Nitrogen retained (NR, } \\
\mathrm{g} / \mathrm{d})^{2}\end{array}$ & $1.29^{\mathrm{b}}$ & $1.55^{\mathrm{a}}$ & $1.42^{\mathrm{a}}$ & $1.52^{\mathrm{a}}$ & 0.05 & 0.0295 \\
\hline $\mathrm{DN} / \mathrm{NI}(\%)^{3}$ & $73.08^{\mathrm{b}}$ & $75.52^{\mathrm{ab}}$ & $75.91^{\mathrm{a}}$ & $75.86^{\mathrm{a}}$ & 0.67 & 0.0533 \\
\hline NR/NI $(\%)^{4}$ & $49.28^{b}$ & $52.56^{\mathrm{a}}$ & $50.86^{\mathrm{ab}}$ & $53.37^{\mathrm{a}}$ & 1.30 & 0.0213 \\
\hline $\mathrm{NR} / \mathrm{DN}(\%)^{5}$ & $67.41^{\mathrm{b}}$ & $69.60^{\mathrm{a}}$ & $66.98^{\mathrm{b}}$ & $70.33^{\mathrm{a}}$ & 1.22 & 0.0235 \\
\hline
\end{tabular}

\#SEM= standard error of the mean.

${ }^{a, b, c}$ Means within a row having different superscripts are significantly different $(P \leq 0.05) .{ }^{1} D N=N I-F N$;

${ }^{2} N R=N I-F N-U N ;{ }^{3} D N / N I(\%)=$ the intake efficiency $N$ converted to digestible $N$.

${ }^{4} N R / N I \%=$ the intake efficiency $N$ converted to retained $N$.

${ }^{5} \mathrm{NR} / \mathrm{DN}(\%)=$ the digestible $N$ efficiency converted to digestible $N$.

\section{Carcass traits:}

Oral administration of anaerobic probiotic $\left(\mathrm{ZAD}^{\circledR}\right)$, on carcass characteristics of growing NZW rabbits is summarized in Table (4). Pre-slaughter weight (g) values ranged from 1860-2093.33 g within significant differences among the different rabbit treatments (Table 4). Dressing, edible giblets, total edible parts and total non-edible parts\% were significantly varied from 57.38-62.61, from 2.51-3.02, from 59.89-65.39 and from 34.61- 40.11, respectively. The highest significant averages of dressing\% was recorded for rabbit intake $0.25 \mathrm{ZAD}^{\circledR}$. However, the higher significant averages of edible giblets\% was recorded for rabbit 
administration orally in $1.0 \mathrm{ZAD}^{\circledR}$. A significant, dose in treatment $0.25 \mathrm{ZAD}^{\circledR}$ increase $(\mathrm{P}=0.0001)$ for total edible parts. An opposite effect was noticed regarding total non-edible parts\%, where, the values were significantly $(\mathrm{P}=0.0001)$ decreased as compared control group.

Table (4): Effects of anaerobic probiotic ZAD® supplement on carcass characteristics\% of growing rabbits.

\begin{tabular}{|c|c|c|c|c|c|c|}
\hline \multirow[t]{2}{*}{ Item } & \multicolumn{4}{|c|}{ Treatment } & \multirow[b]{2}{*}{$\mathrm{SEM}^{\#}$} & \multirow[b]{2}{*}{ P-value ${ }^{2}$} \\
\hline & Control & $\begin{array}{c}0.25 \mathrm{ml} \mathrm{ZAD}^{\circledR} \\
/ \mathrm{rabbit} / \text { day }\end{array}$ & $\begin{array}{c}0.5 \mathrm{ml} \mathrm{ZAD}{ }^{\circledR} \\
/ \text { rabbit/day }\end{array}$ & $\begin{array}{l}1.0 \mathrm{ml} \mathrm{ZAD}^{\circledR} \\
/ \mathrm{rabbit} / \text { day }\end{array}$ & & \\
\hline $\begin{array}{l}\text { Pre-slaughter weight } \\
\text { (g) }\end{array}$ & $1860.0^{\mathrm{b}}$ & $2000.0^{\mathrm{ab}}$ & $2093.3^{\mathrm{a}}$ & $1820.0^{\mathrm{b}}$ & 59.50 & 0.0152 \\
\hline Dressing & $57.38^{\mathrm{c}}$ & $62.61^{\mathrm{a}}$ & $60.40^{\mathrm{b}}$ & $58.72^{\mathrm{bc}}$ & 0.59 & 0.0001 \\
\hline Edible giblets & $2.51^{\mathrm{b}}$ & $2.79^{\mathrm{ab}}$ & $2.73^{\mathrm{ab}}$ & $3.02^{\mathrm{a}}$ & 0.10 & 0.0337 \\
\hline Total edible parts & $59.89^{c}$ & $65.39^{\mathrm{a}}$ & $63.13^{\mathrm{b}}$ & $61.74^{\mathrm{bc}}$ & 0.60 & 0.0001 \\
\hline $\begin{array}{l}\text { Total non-edible } \\
\text { parts }\end{array}$ & $40.11^{\mathrm{a}}$ & $34.61^{\mathrm{c}}$ & $36.87^{\mathrm{b}}$ & $38.26^{\mathrm{ab}}$ & 0.60 & 0.0001 \\
\hline Liver & $1.70^{\mathrm{b}}$ & $1.85^{\mathrm{a}}$ & $1.89^{\mathrm{a}}$ & $1.89^{\mathrm{a}}$ & 0.04 & 0.0160 \\
\hline Heart & 0.22 & 0.23 & 0.22 & 0.23 & 0.01 & 0.9334 \\
\hline Kidney & 0.53 & 0.52 & 0.49 & 0.53 & 0.03 & 0.7744 \\
\hline Perirenal fat & $2.82^{\mathrm{a}}$ & $2.31^{\mathrm{b}}$ & $2.41^{\mathrm{b}}$ & $2.38^{\mathrm{b}}$ & 0.07 & 0.0001 \\
\hline Scapular fat & $0.32^{\mathrm{a}}$ & $0.27^{\mathrm{b}}$ & $0.26^{\mathrm{b}}$ & $0.24^{\mathrm{c}}$ & 0.00 & 0.0001 \\
\hline
\end{tabular}

${ }^{\#} S E M=$ standard error of the mean. ${ }^{2 ; a, b, c}$ Means within a row having different superscripts are significantly different $(P \leq 0.05)$.

The percentage of liver in each $\mathrm{ZAD}^{\circledR}$ dosage groups was significantly increased $(\mathrm{P}=0.0160)$ compared to the control group. Anaerobic probiotic ZAD ${ }^{\circledR}$ doses had no significant effects on the percentages of heart and kidney. However, the total edible parts percentage has been augmented $(\mathrm{P}=0.0001)$ and the perirenal fat, and scapular fat percentage were decreased $(\mathrm{P}=0.0001)$ with increasing $\mathrm{ZAD}^{\circledR}$ doses when compared with the control treatment.

The present results are consistent with the findings of Kermauner and Struklec (1996) observed that addition of probiotic Acid-Pack-4-way on the diet of rabbit increased $(\mathrm{P} \leq 0.05)$ the dressing percentage and carcass weight. Also, Fathi et al. (2017) indicated that supplementation of dietary with probiotic compared to other dietary treatments resulted in a significantly higher percentage of dressing.

In our experiment dressing and total edible parts $(\%)$ in group $0.25 \mathrm{ZAD}^{\circledR}$ was significantly increased by 9.12\% and $9.26 \%$ rather than control group, respectively. These results are consistent with the results of Abdel-Azeem et al. (2009) who revealed that NZW rabbits (35 days aged) when received diet supplemented with $20 \mathrm{mg}$ virginiamycin, $100 \mathrm{mg}$ zinc bacitracin, $1.5 \mathrm{~g}$ bioaction (probiotic) and $3.0 \mathrm{~g}$ yeast culture (Saccharomyces cerevisiae) significantly $(\mathrm{P} \leq 0.05)$ increased dressing and carcass weight percentages. However, these results were contrary to El-Sagheer and Hassanein (2014), who found that there were no significant effects of dietary Vetazyme or strain supplementation on rabbit carcass traits excluding the percentage of the liver. Also, Bhatt et al. (2017) as using probiotics (10 $\mathrm{CFU} / \mathrm{g}$ concentrate) Lactococcus lactis and Lactobacillus acidophilus in weaning Chinchilla rabbits diets.

\section{Caecum activity:}

The effect of oral administration anaerobic probiotic $\left(\mathrm{ZAD}^{\circledR}\right)$, on caecum performance, $\mathrm{pH}$, ammonia concentration and VFA, butyric acid $\mathrm{mmol} / \mathrm{L}$, acetic acid $\mathrm{mmol} / \mathrm{L}$, and propionic acid $\mathrm{mmol} / \mathrm{L}$ of growing NZW rabbits is summarized in Table (5). Caecum length $(\mathrm{cm})$, full caecum weight $(\mathrm{g})$, empty caecum weight $(\mathrm{g})$ and caecum $\mathrm{pH}$ significantly varied from 40.47-49.20, from 98.85-120.00, from 25.97-28.87 and 
from 5.73-6.59, respectively. The higher significant averages of caecum length $(\mathrm{cm})$ and caecum $\mathrm{pH}$ were recorded for rabbit received oral administration of $0.25 \mathrm{ZAD}^{\circledR}$. However, higher significant averages of full and empty caecum weight $(\mathrm{g})$ were recorded for rabbit received oral administration of $0.5 \mathrm{ZAD}{ }^{\circledR}$. The opposite trends was observed by ammonia $\mathrm{mmol} / \mathrm{L}$ where it was significantly decreased $(\mathrm{P}=0.0001)$ with increasing oral doses of anaerobic probiotic ZAD ${ }^{\circledR}$.

Table (5): Effect of anaerobic probiotic $\mathrm{ZAD}^{\circledR}$ oral administration on caecum $\mathrm{pH}$ and volatile fatty acids (VFA) of growing rabbits.

\begin{tabular}{|c|c|c|c|c|c|c|}
\hline \multirow[t]{2}{*}{ Item } & \multicolumn{6}{|c|}{ Treatment } \\
\hline & Control & $\begin{array}{l}0.25 \quad \mathrm{ml} \\
\mathrm{ZAD}^{\circledR} \\
/ \mathrm{rabbit} / \mathrm{day}\end{array}$ & $\begin{array}{l}0.5 \mathrm{ml} \mathrm{ZAD}{ }^{\circledast} \\
\text { /rabbit/day }\end{array}$ & $\begin{array}{l}1.0 \mathrm{ml} \mathrm{ZAD}^{\circledR} \\
\text { /rabbit/day }\end{array}$ & SEM $^{\#}$ & $P$-value ${ }^{2}$ \\
\hline $\begin{array}{l}\text { Caecum length } \\
(\mathrm{cm})\end{array}$ & $40.47^{\mathrm{c}}$ & $49.20^{\mathrm{a}}$ & $48.69^{\mathrm{ab}}$ & $48.30^{\mathrm{b}}$ & 0.14 & 0.0001 \\
\hline $\begin{array}{l}\text { Full caecum } \\
\text { weight }(\mathrm{g})\end{array}$ & $98.85^{\mathrm{b}}$ & $116.67^{\mathrm{a}}$ & $120.00^{\mathrm{a}}$ & $105.00^{\mathrm{b}}$ & 1.55 & 0.0007 \\
\hline $\begin{array}{l}\text { Empty caecum } \\
\text { weight }(\mathrm{g})\end{array}$ & $25.97^{\mathrm{b}}$ & $27.33^{\mathrm{ab}}$ & $28.87^{\mathrm{a}}$ & $27.35^{\mathrm{ab}}$ & 0.42 & 0.0182 \\
\hline Caecum pH & $5.73^{c}$ & $6.59^{\mathrm{a}}$ & $6.44^{\mathrm{ab}}$ & $6.17^{\mathrm{b}}$ & 0.09 & 0.0009 \\
\hline $\begin{array}{l}\text { Amonia } \\
(\mathrm{mmol} / \mathrm{L})\end{array}$ & $13.38^{\mathrm{a}}$ & $11.59^{\mathrm{b}}$ & $10.54^{\mathrm{c}}$ & $9.67^{\mathrm{d}}$ & 0.24 & 0.0001 \\
\hline $\begin{array}{l}\text { VFA } \\
(\mathrm{mmol} / \mathrm{L})\end{array}$ & $51.62^{\mathrm{c}}$ & $64.34^{\mathrm{b}}$ & $71.80^{\mathrm{a}}$ & $70.25^{\mathrm{a}}$ & 3.89 & 0.05 \\
\hline $\begin{array}{l}\text { Butyric } \\
(\mathrm{mmol} / \mathrm{L})\end{array}$ acid & $9.14^{\mathrm{b}}$ & $10.23^{\mathrm{a}}$ & $10.30^{\mathrm{a}}$ & $10.15^{\mathrm{a}}$ & 0.17 & 0.0171 \\
\hline $\begin{array}{l}\text { Acetic } \\
(\mathrm{mmol} / \mathrm{L})\end{array}$ acid & $50.40^{\mathrm{d}}$ & $68.95^{\mathrm{a}}$ & $67.09^{\mathrm{b}}$ & $65.49^{c}$ & 0.40 & 0.0001 \\
\hline $\begin{array}{l}\text { Propionic acid } \\
(\mathrm{mmol} / \mathrm{L})\end{array}$ & $5.02^{\mathrm{c}}$ & $6.47^{\mathrm{a}}$ & $6.23^{\mathrm{a}}$ & $5.94^{\mathrm{b}}$ & 0.08 & 0.0001 \\
\hline
\end{tabular}

${ }^{\#}$ SEM $=$ standard error of the mean.

2;a,b,c Means within a row having different superscripts are significantly different $(P \leq 0.05)$.

Compared with the control group, the VFA mmol/L, butyric acid mmol/L,acetic acid mmol/L, and propionic acid $\mathrm{mmol} / \mathrm{L}$ were significantly increased at every administration of anaerobic probiotic ZAD ${ }^{\circledR}$ dose.

The caecum is the rabbit's largest digestive part (forty percent of the entire digestive tract). As a major fermentation site (e.g., degradation of fiber), it acts as a key role in digestion. The present study showed that all rabbits intake orally $\mathrm{ZAD}^{\circledR}$ tends to increase a significant improves in caecum performance and activity. In this connect, Abdel-Aziz et al. (2014) found that feeding rabbits with Lactobacillus acidophilus diet insignificantly decreased the alimentary tract weight (empty) as a percentage of the total body weight than those fed the control diets. Caecum pH is affected by VFA and ammonia resulting from degradation and fermentation of caecal. Our results performed that the improvements in caecum $\mathrm{pH}$ amounted at 56 days of age to $15,12.4$ and $7.68 \%$ for groups $0.25,0.5$ and $1.0 \mathrm{ZAD}^{\circledR}$, respectively. The content of caecum is somewhat acidic (pH 5.4-6.8) (Garcia et al., 2002). Processes of fermentation result in VFA production, butyric acid, acetic acid, propionic acid and ammonia $\left(\mathrm{NH}_{3}\right)$ obtained from proteolysis, while, the VFA and $\mathrm{NH}_{3}$ are absorbed via the colon and caecum walls and are a source of energy for the host.

In this results, caecal ammonia concentrations was reduced $(\mathrm{P}=0.0001)$ by $15.44,27$ and $37.1 \%$ for rabbits intake orally $0.25,0.5$ and $1.0 \mathrm{ZAD}^{\circledR}$, respectively. 
The concentration of VFA in the rabbit caecum is around $75 \%$ acetate, $15 \%$ and $10 \%$ butyrate propionate (Bellier et al., 1995). The high total VFA concentration produced from the caecal content of rabbit's oral intake $\mathrm{ZAD}^{\circledR}$ probiotics indicates high available energy that affected growth performance. The concentration of acetic acid generated from the caecum content of rabbit's administration orally $\mathrm{ZAD}^{\circledR}$ there were also higher numeric values for probiotics. This agreed with previous findings Gado et al. (2017) who showed that inclusion of the ZADO ${ }^{\circledR}$ treatment has been increased $(\mathrm{P} \leq 0.05)$ the rumen ammonia $\mathrm{N}$ and total VFA concentrations before and $3 \mathrm{~h}$ post-feeding.

\section{Bacterial load:}

Table (6) shows the total number of different microbial counts grown on different media as affected by the different oral administration with three doses of $0.25,0.5$ and $1.0 \mathrm{ZAD}^{\circledR}$ comparing with control diet of NZW growing rabbits.

Table (6): Microbial count $\left(\times 10^{5)}\right.$ in the caecum $\left(\mathrm{CFU} / \mathrm{ml}^{-1}\right)$ on MRS broth of NZW growing rabbits oral administration experimental treatments containing different doses of anaerobic probiotic ZAD ${ }^{\circledR}$.

\begin{tabular}{|c|c|c|c|c|c|c|}
\hline \multirow[b]{2}{*}{ Item } & \multicolumn{4}{|c|}{ Treatment } & \multirow[b]{2}{*}{$\mathrm{SEM}^{\#}$} & \multirow[b]{2}{*}{$P$-Value ${ }^{2}$} \\
\hline & Control & $\begin{array}{l}0.25 \mathrm{ml} \mathrm{ZAD}^{\circledR} \\
/ \mathrm{rabbit} / \text { day }\end{array}$ & $\begin{array}{l}0.5 \quad \mathrm{ml} \\
\mathrm{ZAD}^{\circledR} \\
\text { /rabbit/day }\end{array}$ & $\begin{array}{l}1.0 \quad \mathrm{ml} \\
\mathrm{ZAD}^{\circledR} \\
\text { /rabbit/day }\end{array}$ & & \\
\hline Total bacterial & $4.75^{\mathrm{a}}$ & $3.7^{b}$ & $3.1^{\mathrm{b}}$ & $2.91^{b}$ & 0.13 & 0.0001 \\
\hline Total coliform & $3.4^{\mathrm{a}}$ & $3.01^{\mathrm{ab}}$ & $2.79^{\mathrm{b}}$ & $2.61^{b}$ & 0.10 & 0.005 \\
\hline Total anaerobic & $1.91^{\mathrm{a}}$ & $1.42^{\mathrm{ab}}$ & $1.09^{\mathrm{b}}$ & $0.91^{\mathrm{b}}$ & 0.29 & 0.0015 \\
\hline L. acidiophilus & $0.85^{\mathrm{b}}$ & $1.75^{\mathrm{a}}$ & $1.99^{\mathrm{a}}$ & $2.31^{\mathrm{a}}$ & 0.14 & 0.0179 \\
\hline L. cellobiosus & $1.41^{\mathrm{b}}$ & $1.89^{\mathrm{a}}$ & $2.11^{\mathrm{a}}$ & $2.46^{\mathrm{a}}$ & 0.09 & 0.015 \\
\hline
\end{tabular}

${ }^{\#}$ SEM $=$ standard error of the mean.

${ }^{2 ; a, b}$ Means within a row having different superscripts are significantly different $(P \leq 0.05)$.

Colonies grown on plate count agar ranged between $2.91 \times 10^{5}$ and $4.75 \times 10^{5} \mathrm{cfu} / \mathrm{ml}$ as the percentage of anaerobic probiotic $\mathrm{ZAD}^{\circledR}$, decreased the total microbial count.

Colonies appeared on Mckoney agar ranged from $2.61 \times 10^{5}$ for $1.0 \mathrm{ZAD}^{\circledR}$ to $3.4 \times 10^{5} \mathrm{cfu} / \mathrm{ml}$ for 0.0 $\mathrm{ZAD}^{\circledR}$. Similar to total microbial count as the amount of ZAD ${ }^{\circledR}$, the number of coliform group decreased.

The total number of anaerobic bacteria was less than those of total microbial count and coliform group but they have the same trend of decreasing the number as the dose of $Z^{5} D^{\circledR}$ increased. The total number of anaerobic bacteria was ranged between $0.91 \times 10^{5}$ and $1.91 \times 10^{5} \mathrm{cfu} / \mathrm{ml}$.

Fermentation of lactobacilli as L. acidiophilus and L. cellobiosus take opposite trend as the dose of ZAD ${ }^{\circledR}$ increased the L. acidiophilus and L. cellobiosus number increased. It was ranged from $0.85 \times 10^{5}$ and $2.31 \mathrm{x}$ $10^{5} \mathrm{cfu} / \mathrm{ml}$ and $1.41 \times 10^{5}$ and $2.46 \times 10^{5} \mathrm{cfu} / \mathrm{ml}$, respectively.

\section{Isolation and identification of some colonies:}

From the four medium, 91 colonies were isolated, the number and percentages of isolates represents the different microbial counts of the caecum of NZW growing rabbits are found in Tables (7) and (8). Generally, identification were grouped into 6 groups 16 isolates were gram negative, 17 isolates were gram positive, 13 isolates were mixed strains, 19 isolates were gram positive-cocci, 10 isolates were streptococci and 16 isolates are lactobacilli group. Isolates of each bacterial group were shown at the same table as affected by the doses of anaerobic probiotic ZAD ${ }^{\circledR}$. The highest isolates were for gram positive bacteria (19 isolates), while the lowest isolates were for mixed (contaminated). As it is expected streptococci isolates was lower than lactobacilli group. For the first 6 groups as the concentration of anaerobic probiotic ZAD ${ }^{\circledR}$, increased the number of isolates decreased, while lactobacilli enumeration increased with the increase of ZAD ${ }^{\circledR}$, orally 
administration. This is one of the advantages of this anaerobic probiotic $\mathrm{ZAD}^{\circledR}$ administrate orally is to encourage the growth of lactobacilli which is regarded as very useful bacteria in the caecum and possibly to be addition of probiotics. Then by using the biochemical and carbohydrate fermentation testes identify type of useful bacteria (Lactobacillus acidophilus and Lactobacillus cellobiosus isolates from the caecum of rabbit), as shown in Table (9).

Table (7): The numbers and percentage (No, \%) of bacterial isolates from caecum of NZW rabbits administration orally with different doses of anaerobic probiotic ZAD.

\begin{tabular}{lllllll}
\hline & & \multicolumn{5}{l}{ Treatment } \\
\cline { 3 - 7 } Item & No $\%$ & Control & $\begin{array}{l}0.25 \\
\text { ZAD } \\
\text { /rabbit/day }\end{array}$ & $\begin{array}{l}0.5 \mathrm{ml} \text { ZAD }^{\circledR} \\
\text { /rabbit/day }\end{array}$ & $\begin{array}{l}1.0 \\
\text { ZAD }^{\circledR} \\
\text { /rabbit/day }\end{array}$ \\
\hline Gram negative bacteria & $16(17.6)$ & $4(17.4)$ & $4(16.7)$ & $3(15.8)$ & $5(20)$ & $\mathrm{ml}$ \\
Gram positive bacteria & $17(18.7)$ & $5(21.7)$ & $3(12.5)$ & $3(15.8)$ & $6(24)$ \\
Mixed (contaminated) & $13(14.3)$ & $3(13.0)$ & $4(16.7)$ & $3(15.8)$ & $3(12)$ \\
Gram positive cocci & $19(20.9)$ & $5(21.7)$ & $6(25)$ & $4(21.1)$ & $4(16)$ \\
Streptococci & $10(11)$ & $4(17.4)$ & $2(8.3)$ & $2(10.5)$ & $2(8)$ \\
Lactobacilli & $16(17.6)$ & $2(8.7)$ & $5(20.8)$ & $4(15.8)$ & $5(16)$ \\
Total & $91(100)$ & $23(33.3)$ & $24(21.2)$ & $19(21.1)$ & $25(20)$ \\
\hline
\end{tabular}

The adverse effects of bacterial diseases are a major concern to the rabbit production especially those dealing in economically viable species like the growing rabbits (Bagone Vantus et al., 2014). Due to increased growing rabbits mortality and poor performance, farmers have turned to the use of commercial antibiotics to salvage their investments. The prolonged use of antibiotics has significant public health consequences on the environment as well as spawning antibiotic resistant pathogens (Alderman and Hastings, 1998). As an alternative, probiotic organisms have been suggested (Verschuere et al., 2000). Results indicated that the total microbial, total coliform count and total anaerobic count markedly decreased with increasing doses of anaerobic probiotic $\mathrm{ZAD}^{\circledR}$, in this respect Oso et al. (2013) said that rabbits consumed diets including several additives as mannan oligosaccharides $(1 \mathrm{~g} / \mathrm{kg})$, Prediococcus acidilactis $\left(1 \times 10^{10} \mathrm{cfu} / \mathrm{g} ; 0.5 \mathrm{~g} / \mathrm{kg}\right)$, arabinoxylans oligosaccharides $(1 \mathrm{~g} / \mathrm{kg})$, oxytetracy-cline $(1 \mathrm{~g} / \mathrm{kg})$, Bacillus cereus $\left(1 \times 10^{9} \mathrm{cfu} / \mathrm{g} ; 0.5 \mathrm{~g} / \mathrm{kg}\right)$, caused a reduction of count of coliform in their caecum content when compared to those consumed the control diet.

The opposite trend was observed in lactobacillus number that increase with addition different doses of probiotic $\mathrm{ZAD}^{\circledR}$, as well as the lactobacilli numbers in the cecum, ileum, and the mean number in all gut segments of the rabbits fed diets including $0.5 \times 10^{6} \mathrm{cfu} / \mathrm{g} \mathrm{B}$. subtilis plus $0.5 \times 10^{7} \mathrm{cfu} / \mathrm{g} \mathrm{L}$. acidophilus or $1 \times 10^{7} \mathrm{cfu} / \mathrm{g}$ L. acidophilus were higher $(\mathrm{P} \leq 0.001)$ than those of rabbits fed diets including $1 \times 10^{6} \mathrm{cfu} / \mathrm{g} B$. subtilis, or those have no probiotic in their diet (Phuoc and Jamikorn 2017). In a rabbit, Foster et al, (1980) found that the model of $E$. coli enterotoxin-induced diarrhea and injected the infected ileal loops with a Lactobacillus-containing preparation the results was a significant anti-enterotoxin response.

From the four medium, 91 colonies were isolated, the highest isolates were for gram positive bacteria (17 isolates), while, the lowest isolates were for mixed (contaminated). As it is expected streptococci isolates (10 isolates) was lower than lactobacilli group. Results obtained those lactobacilli enumeration increased with the increase of anaerobic bacteria of $\mathrm{ZAD}^{\circledR}$ oral administration. This is one of the advantages of this anaerobic bacteria mixed enzymes is to encourage the growth of lactobacilli which is regarded as very useful bacteria in the caecum and possibly to be a member of probiotics. 
Table (8): Identification of bacteria Lactobacillus acidophilus and Lactobacillus cellobiosus isolates from the caecum of NZW growing rabbit intake orally by different doses of anaerobic probiotic ZAD.

\begin{tabular}{lcc}
\hline CODE & Lactobacillus acidophilus & Lactobacillus cellobiosus \\
\hline Arabinose & - & $\mathrm{V}$ \\
Glucose & + without & + \\
Lactose & + & $\mathrm{V}$ \\
Maltose & + & + \\
Sorbitol & + & $\mathrm{V}$ \\
Sucrose & + & $\mathrm{V}$ \\
Malate & $\mathrm{V}$ & + \\
Mannitol & $\mathrm{V}$ & + \\
Mannose & $\mathrm{V}$ & + \\
Trehalose & $\mathrm{V}$ & + \\
Dextrose & + & + \\
Salicin & + & $\mathrm{V}$ \\
Fructose & + & + \\
\hline
\end{tabular}

$(+)=$ Positive, $(-)=$ Negative $;$ NR $=$ Not recognized;

$V=$ Variable $;$ VP = Voges-Proskauer Test

Table (9): Carbohydrate fermentation by Lactobacillus acidophilus and Lactobacillus cellobiosus isolates from the caecum of NZW growing rabbit intake orally by different doses of anaerobic probiotic ZAD.

\begin{tabular}{lcc}
\hline Test & Lactobacillus acidophilus & Lactobacillus cellobiosus \\
\hline Color & Yellow & Yellow \\
Shape & Rods & Rods \\
Gram stain & + & + \\
Oxidative & + & + \\
Catalase & - & + \\
Citrate, Simmons & NR & V \\
Gelatinase & NR & + \\
Indole & + & V \\
Motility & - & + \\
VP & - & + \\
$\mathrm{H}_{2} S$ & - & $\mathrm{V}$ \\
Urease & + & + \\
Methyl Red & - & - \\
\hline
\end{tabular}

$(+)=$ Fermented,$(-)=$ Not fermented $;$ V = Variable

\section{Serum blood biochemical components:}

Table (10) displayed that the effect of anaerobic probiotic oral administration $\left(\mathrm{ZAD}^{\circledR}\right)$ on some serum biochemical blood parameters of growing NZW rabbits. Serum biochemical components data indicated that the serum TP, A, G, and A/G concentration of rabbits received anaerobic probiotic (ZAD®) groups were significantly augmented compared to those group of control. Increased TP and A of growing rabbits received anaerobic probiotic $(\mathrm{ZAD} \AA)$ oral administration was an indication of the relatively good quality of protein and the dietary protein level and availability. Additionally, TP and A were also within healthy rabbit ranges (Ajayi and Raji, 2012). This refers to the anaerobic probiotic was improved relatively dietary protein quality and availability. Higher TP and A values within a normal range obtained from the rabbits received 1.0 ZAD ${ }^{\circledR}$ groups indicates that the high $\mathrm{ZAD}^{\circledR}$ level was safe and beneficial. The protein and globulin are the part of immunity components that albumin-based antibodies are the main protein component of serum which synthesized in the hepatic tissues, which acts the response of humoral immune and that could support the 
augmentation of immune organs. Accordingly, in the current study, findings of globulin levels in serum are supported by Gao et al. (2007), who recommended that supplementing xylanase to wheat-based cockerel diets from 7 to $21 \mathrm{~d}$ of age augmented the response of humoral immune. The functions of albumin include regulation of the distribution of extracellular fluid, and transport agent of many substances as bilirubin, fatty acids, hormones, and vitamins (Attia et al., 2015). These results, in turn, affected the A/G ratio as in the other treatment groups it descended from 0.966 in the control to 0.843 to 0.887 . The reduction in the $\mathrm{A} / \mathrm{G}$ ratio may indicate an augment in the immunity of rabbits.

Serum levels of cholesterol, LDL, vLDL, triglycerides, total lipids, and LDL/ HDL ratio were significantly decreased $(\mathrm{P} \leq 0.05)$ with augmenting levels of anaerobic probiotic oral administration. But, the HDL/total cholesterol and HDL/LDL ratio augmented significantly $(\mathrm{P} \leq 0.001)$ with anaerobic probiotic oral administration $(\mathrm{ZAD} \circledast)$ levels. The results revealed a significant enhancement in good cholesterol (HDL) and HDL: LDL ratio from (3.28 to $7.54 \%$ and 0.15 to $7.68 \%$ ) with ZAD ${ }^{\circledR}$, respectively. Hermansen et al. (2003) stated that the ratio of LDL: HDL ratio is a robust heart events predictor. Findings (Table 10) showed that the LDL: HDL ratio decreased by $0.07 \%$ to $7.1 \%$ with anaerobic probiotic oral administration $\left(\mathrm{ZAD}^{\circledR}\right)$ levels. The current experiment has shown a positive effect on the decrease of serum lipid metabolites from anaerobic probiotic oral administration $\left(\mathrm{ZAD}^{\circledR}\right)$, indicating that supplementation of enzymes could play a role in the metabolism of rabbit. The results showed significant improvement in good cholesterol from 3.28 to $7.54 \%$ lipids. Regrettably, slight reports on the influences of enzyme supplementation on blood lipid metabolites in rabbit diets published. By supplementing enzymes, it can inhibit the merger of ${ }^{14} \mathrm{C}$-labeled acetate to the non-saponifiable lipid fraction and therefore decrease the biosynthesis of lipid profiles and /or may have indirect inhibitory effects in the lipid biosynthesis enzyme hydroxymethyl-glutaryl coenzyme-A reductase levels (Fukushima and Nakano, 1995). This would indicate to the anaerobic probiotic oral administration of rabbit could reduce the lipid profile of serum, and thus aiding to reduce total cholesterol deposition in the muscles and skin. This also means the possibility of incorporating the anaerobic probiotic oral administration $\left(\mathrm{ZAD}^{\circledR}\right)$ which will lead to products of an animal with the decreased cholesterol. The decline in rabbit serum cholesterol levels received anaerobic probiotic oral $\left(\mathrm{ZAD}^{\circledR}\right)$ is likely to indicate an overall decline in the mobilization of lipid.

With respect to kidney functions; creatinine $(\mathrm{mg} / \mathrm{dl})$ and urea $(\mathrm{mg} / \mathrm{dl})$ were not significantly affected by $\mathrm{ZAD} \otimes(\mathrm{P}>0.05)$ and noted that numerical reduction creatinine and urea value for 0.25 and $0.50 \mathrm{ZAD}^{\circledR}$ groups, respectively. That refers to the $\mathrm{ZAD}^{\circledR}$ levels were safe and healthy.

With regard to liver function stated as ALT and AST enzymes of serum, the data documented in Table (10) obviously reveal were significantly decreased $(\mathrm{P} \leq 0.05)$ with augmenting levels of anaerobic probiotic oral administration. Serum liver enzymes activities values (ALT and AST) in the current trial are within the normal range (Ajayi and Raji, 2012). Levels of serum ALT and AST activity are those commonly utilized specifically to diagnose domestic animal hepatic damage and are utilized to detect bile obstruction (i.e. mild and progressive liver damage) (McGill, 2016). That none of these blood metabolites changed between groups received $\mathrm{ZAD}^{\circledR}$ and that they all fell within normal ranges for rabbits insinuate that no liver damage had occurred. Rabbits, particularly those receiving the high level of $\mathrm{ZAD}^{\circledR}$ at this experiment, indicated no clinical signs of toxicity or signs of morbidity, additional the high level of $Z^{2} D^{\circledR}(1 \mathrm{ml}$ each day) was safe and healthy.

Liong and Shah (2005), Sudha et al. (2009), Ooi and Liong (2010), and Abdelhady and El-Abasy (2015) stated alike results. They assumed that the microorganism probiotic effect on lipid metabolism as some microorganisms such as Lactobacillus and Bifidobacterium pose activity of bile salt hydrolase and cholesterol merger or combining to bacteria, and probiotic bacteria creating short-chain fatty acids. Likewise, decrease serum cholesterol of broiler chickens supplemented with probiotic diet may be ascribed to lower synthesis and/or cholesterol absorption in the gut (Mohan et al., 1995\&1996 and Safaa, 2013).

\section{CONCLUSION}

The present study concludes that anaerobic probiotic ZAD ${ }^{\circledR}$ positively improved growth performance and mortality of NZW rabbits as well as improved the nutrient digestible coefficient and nitrogen balance. In addition, this study found that the optimum rate of probiotic ZAD ${ }^{\circledR}$ in the rabbit practical intake orally is 0.25 or $0.5 \mathrm{ml} / \mathrm{rabbit}$ as growth promoter for rabbits without any adverse effects on rabbit growth and increase the concentration of Lactobacillus number in the caecum. As well as the enhancement of some blood biochemical parameters such as decline the lipid profile of serum. 
Table (10): Effects of ZAD ${ }^{\circledR}$ supplement on some blood biochemical parameters of growing rabbits.

\begin{tabular}{|c|c|c|c|c|c|c|}
\hline \multirow[b]{2}{*}{ Item } & \multicolumn{4}{|c|}{ Treatment } & \multirow[b]{2}{*}{$\mathrm{SEM}^{\#}$} & \multirow{2}{*}{$\begin{array}{l}\text { P- } \\
\text { value }^{2}\end{array}$} \\
\hline & Control & $\begin{array}{l}0.25 \mathrm{ml} \mathrm{ZAD}^{\circledR} \\
\text { /rabbit/day }\end{array}$ & $\begin{array}{c}0.5 \mathrm{ml} \mathrm{ZAD}{ }^{\circledR} \\
/ \text { rabbit/day }\end{array}$ & $\begin{array}{c}1.0 \mathrm{ml} \mathrm{ZAD}^{\circledR} \\
\text { /rabbit/day }\end{array}$ & & \\
\hline \multicolumn{7}{|c|}{ Serum protein metabolites: } \\
\hline $\begin{array}{l}\text { Total } \\
(\mathrm{mg} / \mathrm{dl})\end{array}$ & $5.34^{\mathrm{c}}$ & $6.15^{\mathrm{b}}$ & $6.75^{\mathrm{ab}}$ & $7.14^{\mathrm{a}}$ & 0.38 & 0.041 \\
\hline Albumin (mg/dl) & $2.58^{\mathrm{c}}$ & $2.89^{\mathrm{b}}$ & $3.13^{\mathrm{ab}}$ & $3.32^{\mathrm{a}}$ & 0.16 & 0.032 \\
\hline Globulin (mg/dl) & $2.67^{\mathrm{c}}$ & $3.26^{\mathrm{b}}$ & $3.62^{\mathrm{a}}$ & $3.82^{\mathrm{a}}$ & 0.13 & 0.007 \\
\hline Albumin / Globulin & $0.966^{\mathrm{a}}$ & $0.887^{\mathrm{b}}$ & $0.865^{\mathrm{bc}}$ & $0.843^{\mathrm{c}}$ & 0.81 & 0.052 \\
\hline \multicolumn{7}{|c|}{ Serum lipid metabolites: } \\
\hline Total lipid (mg/dl) & $250.56^{\mathrm{a}}$ & $214.82^{\mathrm{b}}$ & $212.13^{\mathrm{b}}$ & $211.82^{\mathrm{b}}$ & 12.21 & 0.010 \\
\hline Triglyceride (mg/dl) & $76.81^{\mathrm{a}}$ & $62.14^{\mathrm{b}}$ & $59.58^{\mathrm{b}}$ & $56.73^{\mathrm{b}}$ & 4.87 & 0.050 \\
\hline $\begin{array}{l}\text { Total cholesterol } \\
(\mathrm{TC}, \mathrm{mg} / \mathrm{dl})\end{array}$ & $67.41^{\mathrm{a}}$ & $62.00^{\mathrm{b}}$ & $58.95^{\mathrm{bc}}$ & $55.3^{c}$ & 3.13 & 0.031 \\
\hline $\mathrm{HDL}(\mathrm{mg} / \mathrm{dl})$ & $20.53^{\mathrm{a}}$ & $19.56^{\mathrm{ab}}$ & $18.92^{\mathrm{b}}$ & $18.12^{\mathrm{b}}$ & 2.03 & 0.050 \\
\hline $\mathrm{LDL}(\mathrm{mg} / \mathrm{dl})$ & $31.52^{\mathrm{a}}$ & $30.01^{\mathrm{ab}}$ & $28.11^{\mathrm{b}}$ & $25.84^{\mathrm{c}}$ & 2.86 & 0.051 \\
\hline $\mathrm{vLDL}(\mathrm{mg} / \mathrm{dl})$ & $15.36^{\mathrm{a}}$ & $12.43^{\mathrm{b}}$ & $11.92^{\mathrm{b}}$ & $11.34^{\mathrm{b}}$ & 1.81 & 0.020 \\
\hline HDL/ TC ratio & $0.305^{\mathrm{b}}$ & $0.315^{\mathrm{a}}$ & $0.321^{\mathrm{a}}$ & $0.328^{\mathrm{a}}$ & 0.02 & 0.001 \\
\hline $\mathrm{LDL} / \mathrm{TC}$ ratio & $0.468^{\mathrm{c}}$ & $0.484^{\mathrm{a}}$ & $0.477^{\mathrm{b}}$ & $0.467^{\mathrm{c}}$ & 0.04 & 0.053 \\
\hline HDL/ LDL ratio & $0.651^{\mathrm{c}}$ & $0.652^{\mathrm{c}}$ & $0.673^{\mathrm{b}}$ & $0.701^{\mathrm{a}}$ & 0.05 & 0.031 \\
\hline LDL/ HDL ratio & $1.535^{\mathrm{a}}$ & $1.534^{\mathrm{a}}$ & $1.486^{\mathrm{b}}$ & $1.426^{\mathrm{b}}$ & 0.59 & 0.022 \\
\hline \multicolumn{7}{|c|}{ kidney function: } \\
\hline Creatinine $(\mathrm{mg} / \mathrm{dl})$ & 0.61 & 0.60 & 0.59 & 0.63 & 0.04 & 0.178 \\
\hline Urea (mg/dl) & 60.56 & 58.38 & 59.76 & 61.22 & 2.79 & 0.954 \\
\hline \multicolumn{7}{|c|}{ Liver function: } \\
\hline ALT (IU) & $37.13^{\mathrm{a}}$ & $30.26^{\mathrm{b}}$ & $29.17^{\mathrm{b}}$ & $28.31^{\mathrm{b}}$ & 0.29 & 0.0467 \\
\hline AST (IU) & $68.21^{\mathrm{a}}$ & $58.83^{\mathrm{b}}$ & $56.31^{\mathrm{b}}$ & $54.36^{\mathrm{b}}$ & 0.63 & 0.0317 \\
\hline
\end{tabular}

\section{REFERENCE}

Abdel-Azeem, F., N.A. Hashem, Y.K.E.H. Badawi and A. Farid (2009). Comparative study between probiotic (Bioplus 2B) and antibiotic (Lincofeed) on the performance of growing rabbits. Egypt. J. Rabbit Sci., 19: 7-22.

Abdel-Aziz, N. A., M. El-Adawy, Maria A. Mariezcurrena-Berasain, A.Z.M. Salem, J. Olivares-Perez, A. E. Kholif and B.E. Borhami (2015). Effects of exogenous enzymes, Lactobacillus acidophilus or their combination on feed performance response and carcass characteristics of rabbits fed sugarcane bagasse. J. Integra. Agric., 14: 544-549.

Abdel-Aziz, N. A., M. El-Adawy, A.Z.M. Salem, M.A. Cerrillo-Soto, L.M. Camacho, B.E. Borhami (2014). Effects of exogenous enzymes, Lactobacillus acidophilus or their combination on feed intake, digestibility and performance of rabbits fed sugarcane bagasse. Anim. Nut. Feed Tech., 14: 137-145.

Abdelhady, D.H. and M.A. El-Abasy (2015). Effect of prebiotic and probiotic on growth, immunohematological responses and biochemical parameters of infected rabbits with Pasteurella multocida. Benha Vet. Med. J., 28(2):40-51, Conference Issue.

Ajayi, A.F. and Y. Raji (2012). Hematological and serum biochemical indices of pre-pubertal male rabbits fed with graded level of blood-wild sunflower forage meal mixture. Afri. J. Biot., 11(35): 8730-8734.

Alderman, D. and T. Hastings (1998). Antibiotic use in aquaculture: Development of antibiotic resistancepotential for consumer health risks. Int. J. Food Sci. \& Tech., 33:139-155. 
Amber K.H., H.M. Yakout and R.S. Hamed (2004). Effect of feeding diets containing yucca extract or probiotic on growth, digestibility, nitrogen balance and caecal microbial activity of growing New Zealand white rabbits. Proc. the $8^{\text {th }}$ World Rabbit Con., Puebla (México), 737-741.

AOAC (2000). Association of Official Analytical Chemists. Official Methods of Analysis, $17^{\text {th }}$ Ed. AOAC, Washington, DC, USA.

Attia, Y.A., F. Bovera, W.S. El-Tahawy, A.M. El-Hanoun, M.A. Al-Harthi and H.I. Habiba (2015). Productive and reproductive performance of rabbits does as affected by bee pollen and/or propolis, inulin and/or mannan-oligosaccharides. World Rabbit Sci., 23(4): 273-282.

Bagone Vantus, V., M. Kovacs and A. Zsolnai (2014): The rabbit caecal microbiota: development, composition and its role in the prevention of digestive diseases - a review on recent literature in the light of molecular genetic methods. Acta Agraria Kaposváriensis, 18(1): 55-65.

Bellier R., T. Gidenne, M. Vernay and M. Colin (1995). In-vivo study of circadian variations of the cecal fermentation pattern in postweaned and adult-rabbits. J. Anim. Sci., 73: 128-135.

Bhatt, R.S., A.R. Agrawal and A. Sahoo (2017). Effect of probiotic supplementation on growth performance, nutrient utilization and carcass characteristics of growing Chinchilla rabbits. J. Appl. Anim. Res., 45(1): 304-309.

Bogin, E. and P. Keller (1987). Application of clinical biochemistry-try to medically relevant animal models and standardization and quality control in animal biochemistry. J. Clin. Chem. Biochem., 25: 873-878.

Burstein, M., H.R. Scholnick and R. Morfin (1970). Rapid method for the isolation of lipoproteins from human plasma by precipitation with polyanions. J. Lipid. Res., 11:583-595.

Cheeke, P.R. (1987). Rabbit Feeding and Nutrition. Academic Press, INC.

Duncan, D.B. (1955). Multiple range and F. test. Biometric., 11:1-42.

Eiben, C. S., M. Mézes, N. Szijártó, K. Kustos, K. Gódor-Surmann and M. Erdélyi (2004). Dose-dependent effect of cellulase supplementation on performance of early-weaned rabbit. Proc. $8^{\text {th }}$ World Rabbit Con., Puebla, México.799-804.

El-Hindawy, M.M., K.A. Yamani and M.I. Tawfeek (1993): Effect of probiotic (LactoSacc) in diets with different protein levels on growth performance, digestibility and some carcass aspects of growing rabbits. Egypt. J Rabbit Sci., 3:13-28.

El-Sagheer, M. and H. H. M. Hassanein (2014). Effect of enzymes and probiotic mixture supplementation to the diet of growing female rabbits on performance and carcass criteria. Egypt. Poult. Sci., 34(I): 259-272.

Fabiny, D.L. and G. Ertingshausen (1971). Automated reaction-rate method for determination of serum creatinine with the centrifichem. Clin. Chem., 17(8): $696-700$.

Fathi, M., M. Abdelsalam, I. AL-Homidan, T. Ebeid, M. EL-Zarei, and O. Abou-Emera, (2017). Effect of probiotic supplementation and genotype on growth performance, carcass traits, hematological parameters and immunity of growing rabbits under hot environmental conditions. Anim. Sci. J., 88: 1644-1650.

Fawcett, J.K. and J.E. Scott (1960). A Rapid and Precise Method for the Determination of Urea. J. Clin. Path., 13, 156-159.

Foster. T.L., L.Jr. Winans and T.R. Carski (1980). Evaluation of lactobacillus preparation on eterotoxigenic E. Coli-induced rabbit ileal loop reactions. Am. J. Gastroenterol, 73: 238-243.

Fringes, C.S., T.W. Fendly, R.T. Rum, and C.A. Queen (1972). Improved determination of total plasma lipids by the soulfo-phospho-vanilin reaction. Clin. Chim., 18: 673-674.

Fukushima, M. and M. Nakano (1995). The effect of probiotic on faecal and liver lipid classes in rats. Br. J. Nut., 73: $701-710$.

Gado, H.M. (1997). Effect of enzymatic treatments for poor quality roughage on fibre digestibility and nitrogen metabolism in baladi goats. Egypt. J. Nut. Feeds, 1: 49-56. 


\section{Abbdel-Azeem et al.}

Gado, H.M. and A.Z.M. Salem (2013). Anaerobic Enzymes as a New Technology in Animal Feed. In: Salem, A. Z. M. (Editor) Nutritional Strategies of Animal Feed Additives. Nova Science Publishers, Inc. New York, chapter 1: 1-24.

Gado, H.M. and A.Z.M. Salem (2014). Influence of anaerobic probiotic on some physiological aspects and reproductive capability of pre-mature rabbits. Abstracts of The $5^{\text {th }}$ Am. Rabbit Congress Toluca, Estado De México, Mexico, September 8-11, 2014 World Rabbit Sci., 2015, 23: 55-86.

Gado, H.M., A. Khusro and A.Z.M. Salem, (2017). Role of probiotics in animal nutrition. Anim. Rev., 4(1): 8-20.

Gado, H.M., A.Z.M. Salem, N.E. Odongoand and B.E. Borhami (2011). Influence of exogenous enzymes ensiled with orange pulp on digestion and growth performance in lambs. Anim. Feed Sci. Tech., 165: 131-136.

Gao, F., Y. Jiang, G.H. Zhou and Z.K. Han (2007). The effects of xylanase supplementation on growth, digestion, circulating hormone and metabolite levels, immunity and gut microflora in cockerels fed on wheat-based diets. Br. Poult. Sci., 48: 480-488.

García, J., T. Gidenne, L. Falcao-E-Cunhaand and C. De Blas (2002). Identification of the main factors that influence caecal fermentation traits in growing rabbits. Anim. Res., 51: 165-173.

Hermansen, K., B. Dinesen, L.H. Hoie, E. Morgenstern, J. Gruenwald (2003). Effects of soy and other natural products on LDL: HDL ratio and other lipid parameters: a literature review. Adva. Ther., 20: 5078.

Jensen, B. (1980). Tissue cleansing through bowel management. Bernard Jensen International, New York.

Johnson, A.M., E.M. Rohlfs and L.M. Silverman (1999). Proteins. In: Burtis C.A. and E.R. Ashwood (eds). Tietz textbook of clinical chemistry, $3^{\text {rd }}$ Ed., W.B. Saunders Company, Philadephia, 477-540.

Kamra D.N., L.C. Chaudhary, R. Singh and N.N. Pathak (1996). Influence of feeding probiotics on growth performance and nutrient digestibility in rabbits. World Rabbit Sci., 4:85-88.

Kermauner, A. and M. Struklec (1996). Addition of probiotic to feeds with different energy and ADF content in rabbits, effect on the digestive organs. World Rabbit Sci., 4: 187-193.

Kermauner, A. and M. Štruklec (1999). Effect of some probiotics on intestinal viscosity in rabbits. ActaAgraria Kap., 3: 165-173.

Kritas, S. K., E.I. Petridou, P.E. Fortomaris, G. Tzika and G. Arsenos Koptopoulos (2008). The effect of probiotics on microbiology, health and performance of fattening rabbits. Asian-Aust. J Anim. Sci., 21: 1312-1317.

Lebas, F. (2004). Reflections on rabbit nutrition with a special emphasis on feed ingredients utilization. Paper presented at: the $8^{\text {th }}$ World Rabbit Con., Sep 7-10; Puebla, Mexico. 686-736.

Liong, M.T. and N.P. Shah (2005). Acid and bile tolerance and cholesterol removal ability of Lactobacilli strains. J. Dairy Sci., 88:55-66.

Mateos, G.G., P.G. Rebollar and C. De Blas (2010). Minerals, vitamins and additives. In: de Blas C., Wiseman J., Eds. Nutrition of the rabbit, $2^{\text {nd }}$ Ed. Cambridge: CAB International, 119-150.

Matusevičius, P., L. Ašmenskaitè, A. Žilinskienė, A. Gugolek, M.O. Lorek and A. Hartman (2006). Effect of probiotic bioplus $2 \mathrm{~B}^{\circledR}$ on performance of growing rabbit. Vet. Ir. Zoot., 36 (58).

McGill, M.R. (2016). The past and present of serum aminotransferases and the future of liver injury biomarkers. ExcliI J., 15: 817-828.

Mohan, B., R. Kadirvel, M. Bhaskaran, and M. Natarajan (1995). Effect of probiotic supplementation on serum/yolk cholesterol and on egg shell thickness in layers. Br. Poult. Sci., 36: 799-803.

Mohan, B., R. Kadirvel, M. Natarajan and M. Bhaskaran (1996). Effect of probiotic supplementation on growth, nitrogen utilization and serum cholesterol in broilers. Br. Poult. Sci., 37: 395-401.

NRC, National Research Council (1977). Nutrient requirements of Rabbits ( $2^{\text {nd }}$ rew.ed.). National Academy of Science, Washington, DC. USA. 
Ooi, L.G. and M.T. Liong (2010). Cholesterol-lowering effects of probiotics and prebiotics: A review of in vivo and in vitro findings. Int. J. Mol. Sci., 11: 2499-2522.

Oso, A.O., O.M.O. Idowu, A.S. Haastrup, A.J. Ajibade, K.O. Olowonefa, A.O. Aluko, A.M. and Barngbose (2013). Growth performance, apparent nutrient digestibility, caecal fermentation, ileal morphology and caecal microflora of growing rabbits fed diets containing probiotics and prebiotics. Lives. Sci., 157: 184190.

Pal, V., M. Jamuna and K. Jeevaratnam (2005). Isolation and characterization of bacteriocin producing lactic acid bacteria from a South Indian special dosa (appam) batter. J. Cult. Collect., 4:53-60.

Phuoc, T.L. and U. Jamikorn (2017). Effects of probiotic supplement (Bacillus subtilis and Lactobacillus acidophilus) on feed efficiency, growth performance, and microbial population of weaning rabbits. Asian-Aust. J. Anim. Sci., 30 (2): 198-205.

Reitman, S. and S. Frankel (1957). A colorimetric method for the determination of serum glutamic oxalacetic and glutamic pyruvic transaminases. Am. J. Clin. Pathol., 28 (1): 56-63.

Richmond, W. (1973). Enzymatic determination of cholesterol. Clin. Chem., 19:1350.

Safaa, H.M. (2013). Influence of dietary enzymes prepared at ensiling (ZADO®) from hatch to 42 days of age on productivity, slaughter traits and blood Constituents in broiler chickens. Int. J. Poult. Sci., 12 (9): 529-537.

SAS (2000). SAS/STAT User's Guide (Version 8.1). SAS Inst. Inc., Cary NC, USA.

Schneider, B. H. and W.P. Flatt (1975). The evaluation of feed through digestibility experiments. University of Georgia experiments .University of Georgia Press Athens, Georgia, USA. 423.

Sherif, S. Kh. (2018). Effect of Dietary Additives on Growth Performance, Carcass Traits and Some Blood Constituents of Rabbits. J. Agri. Sci., 10(1): 139-151.

Sudha, M.R., P. Chauhan, K. Dixit, S. Babu and K. Jamil (2009). Probiotics as complementary therapy for hypercholesterolemia. Biol. Med., 1(4): 1-13, Rev. 4.

Thomke, S. and K. Elwinger (1998). Growth promotants in feeding pigs and poultry. Alternatives to antibiotic growth promotants. Annales de Zwtechnie 47: 245-271.

Trocino, A., G. Xiccato, L. Carraro and G. Jimenez (2005). Effect of diet supplementation with Toyocerin (Bacillus cereus var. toyoi) on performance and health of growing rabbits. World Rabbit Sci., 13: 15-26.

Verschuere, L., G. Rombaut, P. Sorgeloos, and W. Verstraete (2000). Probiotic bacteria as biological control agents in aquaculture. Mic. Mol. Bio. Rev., 64: 655-671.

Warner, A.C.I. (1964). Production of volatile fatty acid in the rumen. 1: Method of measurements. Nut. Abstr. Rev., 34: 339 - 410.

Wieland, H. and D. Seidel (1983). A simple specific method for precipitation of low density lipoproteins. J. Lipid Res., 24(7): 904-909.

Yamani, K.A., H. Ibrahim, A.A. Rashwan, K.M. El-Gendy (1992). Effects of a pelleted diet supplemented with probiotic (Lacto-Sacc) and water supplemented with a combination of probiotic and acidifier (Acid Pak 4 Way) on digestibility, growth carcass and physiological aspects of weanling New Zealand White rabbits. J. Appl. Rabbit Res., 15:1087-1100. 
نمو الأرانب، خصائص الأبيحة، الهضم، تخمرات الأعور، الميكروفلورا، وبعض مكونات الام البيوكيمائية المتأثرة

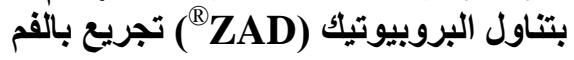

\author{
عبد العظيم سيد عبد العظيم، أيمن حسن2، محمل محم بسيوني²، سلمى هاشم أبو حفصه3

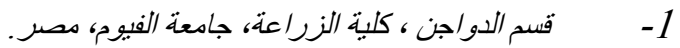

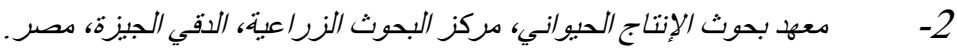

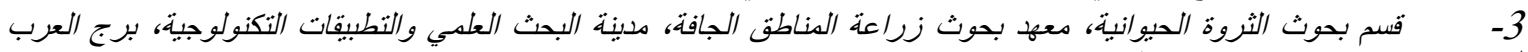 \\ الجديلة، صبب: 21934 الإسكندرية، دصر النغ.
}

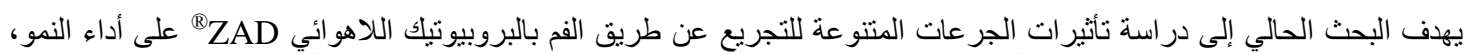

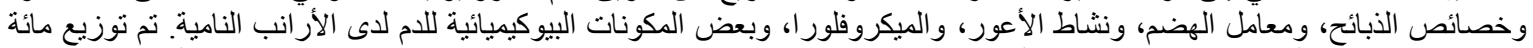

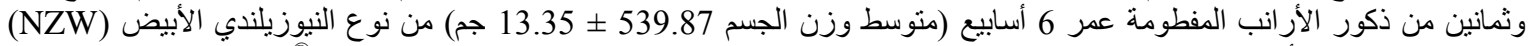

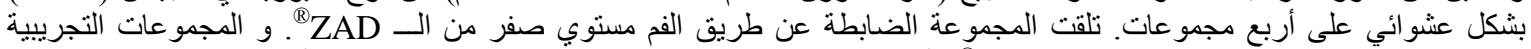
تناولت عن طريق الفم أريع 0.25، 0.5, 1.0 مل ZAD

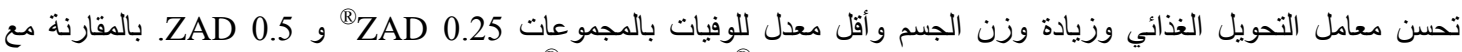

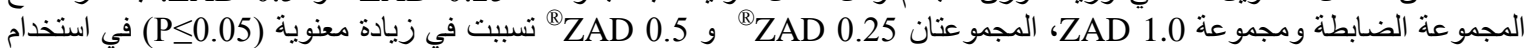

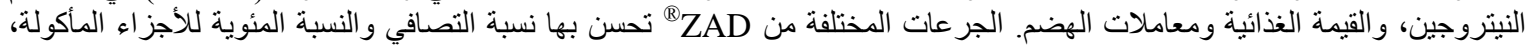

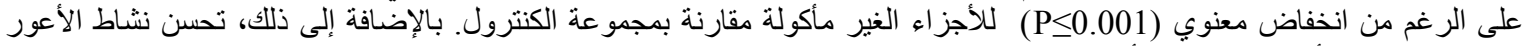

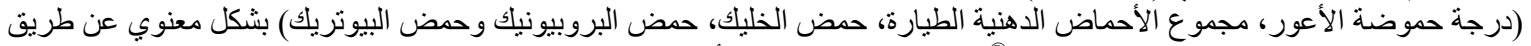
التجريع بجر عات مختلفة من البروبيوتيك ZAD

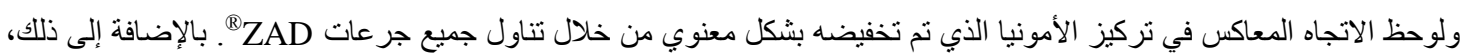

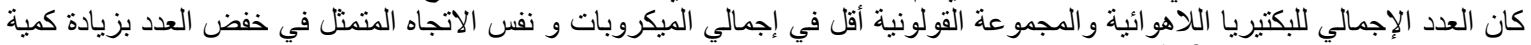

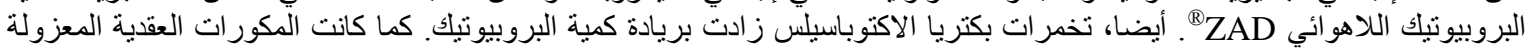

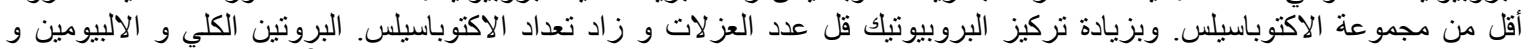

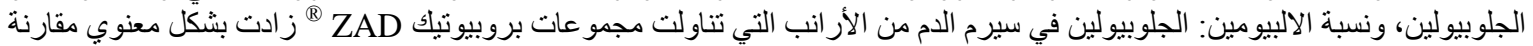

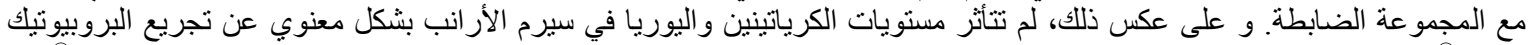

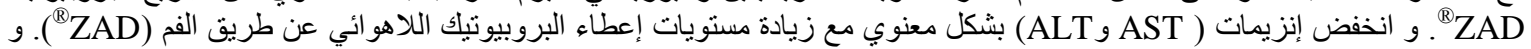

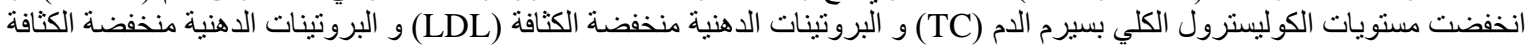

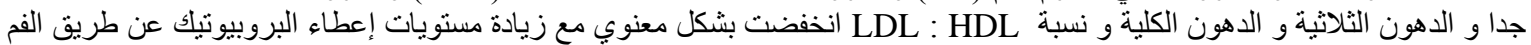

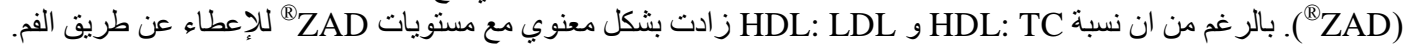
الكلمات الدلة: ZAD) بالرة من أن أداء النمو و معامل الهضم و نثاط الأعور و توازن النيتروجين و الأرنب. 